Cahiers $d u$ MONDE RUSSE

\section{Cahiers du monde russe}

Russie - Empire russe - Union soviétique et États indépendants

$56 / 4 \mid 2015$

Médiateurs d'empire en Asie centrale (1820-1928)

\title{
Paul W. Werth, The Tsar's Foreign Faiths, Toleration and the Fate of Religious Freedom in Imperial Russia
}

Jane Burbank

\section{(2) OpenEdition}

\section{Electronic version}

URL: http://journals.openedition.org/monderusse/8242

DOI: $10.4000 /$ monderusse.8242

ISSN: $1777-5388$

\section{Publisher}

Éditions de l'EHESS

\section{Printed version}

Date of publication: 1 October 2015

Number of pages: $817-820$

ISBN: 978-2-7132-2507-9

ISSN: $1252-6576$

\section{Electronic reference}

Jane Burbank, «Paul W. Werth, The Tsar's Foreign Faiths, Toleration and the Fate of Religious Freedom in Imperial Russia », Cahiers du monde russe [Online], 56/4 | 2015, Online since 01 October 2015, Connection on 23 September 2020. URL : http://journals.openedition.org/monderusse/8242 ; DOI : https://doi.org/10.4000/monderusse.8242 


\title{
Paul W. Werth, The Tsar's Foreign Faiths, Toleration and the Fate of Religious Freedom in Imperial Russia
}

\author{
Jane Burbank
}

\section{REFERENCES}

Paul W. WERTH, The Tsar's Foreign Faiths, Toleration and the Fate of Religious Freedom in Imperial Russia, Oxford : Oxford University Press (Oxford Studies in Modern European History), 2014, 306 p.

1 This compact monograph should become a classic source for students of imperial Russian history. Paul Werth takes up a complex and politically fraught subject-the autocracy's management of non-Orthodox religions-and provides us with a judicious account of both fundamental structures of confessional regulation and modifications introduced to this system during a century of challenges and adjustments. Among this book's outstanding qualities are Werth's refusal to simplify a story that has many seemingly contradictory elements, his consistent striving for accurate representation of initiatives and views, his extraordinarily wide field of sources, and his astute organization of this massive material into a comprehensive, yet nuanced, and dynamic narrative. Let me begin with an attempt to summarize the topics and arguments of this intriguing and important book.

2 Werth takes two approaches to his subject. First, he proposes a framework for understanding the empire's administration of non-Orthodox faiths, a regulatory regime that he calls the "multi-confessional establishment." Second, he poses a normative question: what did this framework mean for religious freedom in the empire? Werth follows this inquiry over a very large space-the whole of the religion-rich territories of 
imperial Russia-and a long, tension-filled time-from the late $18^{\text {th }}$ century to 1914 . The result is a history of imperial management, articulated by reformers, conservatives, ministers and governors, clerics of multiple faiths, petitioners, publicists, jurists, and Duma representatives as they engage in their varied struggles for mostly unlike and often incompatible goals.

3 It is the task of governments to deal with unlike and incompatible goals, and Werth's religious lens offers a revealing look at how the autocracy worked. By the mid-19th century, officials put in place what Werth calls the "multi-confessional establishment." While retaining Russian Orthodoxy as the "predominant" faith (p.48), the administration gradually produced legal regulations and supervisory institutions for at least fifteen non-Orthodox religious groups (Roman Catholics, Greek Catholics, Lutherans, Muslims in different regions, Jews, Buddhists, etc.). A Department for the Spiritual Affairs of the Foreign Confessions under the Ministry of the Interior became the central agency for the management of these confessions. Werth's extremely useful charts capture this regulatory achievement.

4 Along with supervisory success came a certain dose of ideological self-assertion. Recognition of multiple faiths meant that Russia could boast of its regime of religious "tolerance" and its avoidance of the wars of religion that devastated its European neighbors. However, religion like everything else in the $19^{\text {th }}$ century did not hold still. The second part of the book deals with a series of challenges to the multi-confessional establishment.

5 The most recognizable of the empire's problems was nationalism, at least in the eyes of officials who equated religion with ethnicity and saw a Polish revolutionary behind every Catholic in the western regions. But other disruptions came from the seemingly ubiquitous propensity to want to marry someone of the wrong origins (in this case another religion), from the also widespread tendency for religions to spawn new religions (new sects, new orthodoxies, etc.), from imperial competitions (religious reforms in the Ottoman empire, formation of the German empire), from intellectual ferment (atheism, idealism), and, as Werth emphasizes, a deeper appreciation of what Russians' called "freedom of conscience." Werth follows these tendencies and officials' attempts to deal with them through the revolution of 1905, the announcement of the Fundamental Laws, and the Duma years-when both the attempt at representative government and the demand for individualized freedoms proved profoundly disruptive to the multi-confessional establishment.

Where others might reduce these new claims and critiques into stories of religious or colonial persecution, Werth considers with empathy the efforts of officials to deal with problems as they arose and, in some cases, to produce viable reforms. As he shows, some tsarist ministers wanted to allow "freedom of conscience." The problem was how to bring this about in the face of several huge obstacles. The most obvious of these was the Orthodox church with its not paranoid fear of losing adherents. But there was also the fact that religion underlay the legal structure of the empire and not least provided the means by which subjects were registered and supervised. Allowing complete individual freedom to choose one's religion, or no religion, would mean undermining the whole regulatory edifice. Werth emphasizes other stumbling blocks, in particular the tension between administrators' understanding of reform as improving regulation, and subjects' expectation that reform would mean less intrusion into their spiritual practices. 
7 Officials did try to renovate. In a thought-provoking chapter on freedom of conscience as a legislative project, Werth reveals the efforts made from 1905 to 1909 to change the laws on conversion, mixed marriage, and other matters related to the regulation and rights of confessional groups and individuals. The initial breakthrough was made with the decree of 17 April 1905 that, among other substantive revisions, legalized conversion from Orthodoxy (aka apostasy) to other Christian confessions. As it turned out, it was easier for the administration to issue this law in unreformed Russia than for the multiple lawmakers active after 1906 to bring to fruition any fundamental change to the multi-confessional establishment.

8 One can only marvel at Werth's ability to bring coherence and provocative analysis to bear on the multiple strands of this complicated story of religion and state power. The book is based on an enormous array of archival and printed sources, from all over the former empire, as well as extensive reading in the primary and secondary literature on many religions and national groups. Werth engages firmly with the recent historiographic dust-ups over the empire's treatment of Islam, gives credit where it is due, ${ }^{1}$ and sustains a modest, forthright tone. He brings a human touch to the narrative, putting several remarkable personalities on display in their own words.

Werth will no doubt be criticized for not giving enough attention to parishioners themselves, but readers should note first, that this book is explicitly about the state's practices; two, that it is impossible to write about everyone in all churches!; and three, the "people" are in fact quite present in the narrative. Many incidents Werth describes reveal that lay people pushed the state to change-with their submission of claims, their enormous numbers of petitions, their refusal to give up their beliefs. These requests bear witness to the participation of subjects in the multi-confessional establishment: petitioners appealed not for release from religious order, but for recognition of their faiths by the state.

10 While Werth's line of argument is consistently clear, fair, and illuminating, I have to raise one concern. This concerns space and time, as deployed in method and interpretation. The analysis is set squarely in a European frame of reference: Russian practices are shown to be more or less similar to those of European governments. It is undeniable that Russia's officials and intellectuals in the $19^{\text {th }}$ century were legitimately concerned about the cultural initiatives of their powerful western imperial challengers -Germany, France, and Great Britain-but historians could ask themselves if "Europe" should constitute the frame of comparison for Russian policies. Somehow we still seem to be caught in the web of Russia's relationship to the "west," even when examining an issue where Russia took a quite distinctive approach to a major question of inclusion and governance.

11 My complaint about time is related to this European fixation, and I lodge it against adjectives such as "archaic," "pre-modern" used to describe Russia's multi-confessional establishment and mode of governance. What this books shows is that there is no neat alignment of time with ruling practice. To put this another way, there is no "age" of one thing or another. The $19^{\text {th }}$ century was at least as imperialist as it was nationalist, and "tolerance" was interpreted in various ways in different places at the same time. In the years covered by this book, European culture exercised a strong attraction on elites around the world, pushed by the prowess of newly hegemonic empires. The idea of "freedom of conscience" traveled far, in various translations, and many Russian elites wanted to be more "western," more "contemporary" with what they thought to be "the 
times." But Werth's careful dissection of both discourse and action shows that, no matter the verbal gloss and no matter how profound the challenges of democracy and individualized freedom, Russian officials carried out a confessional politics that was fundamentally different from that of their western neighbors. And they carried their preferences, in multiple variants, through the Soviet period, and into today's post-Soviet regulatory regime (spoiler: the note on which this book ends). One may not like the transmuted four-pronged (Orthodoxy, Islam, Judaism, Buddhism) confessional establishment in Russia today, but whatever it is, it is not European and it is not archaic.

This comment is intended to enlarge the already generous frame of reference that Werth offers us in The Tsar's Foreign Faiths. A more worldly perspective would mean opening up further the question of origins of Moscovy's habits of rule, including approaches to religion-what Werth calls "early modern bequests"-and it would force us to confront the ongoing appeal of regulatory confessional politics in large and populous states beyond Europe's confines. But before setting out on those intellectual journeys, read this profound and enlightening book.

\section{NOTES}

1. Werth draws particular attention to the works of Robert D. Crews, For Prophet and Tsar: Islam and Empire in Russia and Central Asia (Cambridge, MA, 2006) and Mikhail Dolbilov, Russkii krai, chuzhaia vera: etnoreligioznaia politika v Litve i Belorusii pri Aleksandre II [Le territoire russe, une autre foi : politique ethnoreligieuse en Lithuanie et en Biélorussie sous Aleksandr II] (M., 2010).

\section{AUTHORS}

\section{JANE BURBANK}

New York University 